\title{
Comparison of Oxygen Consumption of Larval and Juvenile Carp Determined by Three Different Methods
}

\author{
Shin Oikawa and Yasuo Itazawa \\ Department of Fisheries, Faculty of Agriculture, Kyushu University 46-04, Higashi, Fukuoka 812, Japan \\ (Received September 29, 1994)
}

\begin{abstract}
The oxygen consumption of carp of 0.0021-3.5 g ( 1 to 79 days old after hatching) was determined at $25^{\circ} \mathrm{C}$ by three different methods. Oxygen consumption in vivo of intact fish $\left(M_{\text {in vivo }}\right)$ was determined by the semi-closed method and the constant flow method. Oxygen consumption in vitro of minced whole body $\left(M_{\text {in vitro }}\right)$ was determined by manometry.

The relationship between oxygen consumption of an individual fish $\left(M\right.$ in $\left.\mu l \mathrm{O}_{2} \cdot \min ^{-1}\right)$ and body mass ( $W$ in $g$ ) was expressed by the equation $M=\mathrm{a} W$ b. Mass exponent " $\mathrm{b}$ " was 0.831 , and was identical for the three methods. The light condition had an effect on oxygen consumption in the semi-closed method, but not in the constant flow method. The value of " $a$ " was 5.71 in the semi-closed method in the light, 4.56 both in the semi-closed method in the dark and in the constant flow method in the three light conditions, and 2.70 in the manometry method. The difference in the value of " $a$ " among the different methods of respirometry is thought to be due to the difference of activity of fish.
\end{abstract}

Key words: oxygen consumption, larvae and juveniles, respirometry, carp

The rate of respiration or oxygen consumption of intact fish has been extensively studied by several types of respirometry, such as closed, semi-closed, and constant flow methods. The oxygen consumption of larval fish can be determined also by these methods. However, this is not easy because of the small size and fragile body of fish larvae. In particular, larvae hatched from isolated epipelagic eggs such as the eggs of the porgy Pagrus major, which develops a subdermal space for buoyancy, are much smaller and more fragile than larvae hatched from demersal eggs.

Recently, indirect methods have been developed to estimate the larval respiration of fish. ${ }^{1-4)}$ The activity of the electron transport system (ETS) from frozen fish has been introduced as a method of measuring the respiration of intact fish. ${ }^{2,4)}$ We have developed methods to estimate the metabolic rate of a whole fish based on oxygen consumption in vitro of minced tissue of the whole fish determined manometrically ${ }^{\text {l) }}$ or volumetrically. ${ }^{3)}$

However, the relationship between respiration rate in vitro determined by our simple respirometry and that in vivo determined by conventional respirometries has not been clarified. In this study, we determined the rate of oxygen consumption in vivo of intact fish by a semi-closed method and a constant flow method and that in vitro of minced fish by Warburg's manometry with carp ranging from $0.0021 \mathrm{~g}$ ( 1 day old after hatching) to $3.5 \mathrm{~g}$ (79 days old), and discuss the difference of the results due to the different methods of respirometry.

\section{Materials and Methods}

\section{Fish Used}

Experiments were carried out on 680 carp Cyprinus carpio ranging from 0.0021 to $3.5 \mathrm{~g}$ in wet mass (1 to 79 days old after hatching). Fish were hatched and raised at $24-26^{\circ} \mathrm{C}$ in our laboratory by feeding on live water fleas Daphnia pulex for a week after two days old and on a commercial carp diet made from fish meal, wheat flour, soybean cake, vitamins and minerals as well as live water fleas after nine days old. Fish were not fed for $24 \mathrm{~h}$ before analysis.

\section{Respirometry}

1. Metabolism in vivo $\left(M_{\text {in vivo }}\right)$ : The rate of oxygen consumption of intact fish $\left(M_{\text {in vivo }}\right)$ was measured at $25^{\circ} \mathrm{C}$ using two different methods, semi-closed method (Fig. 1)

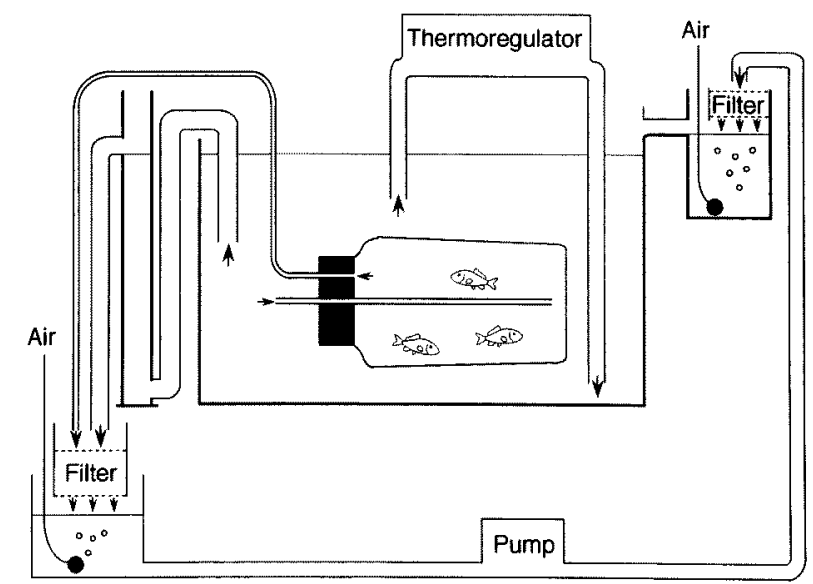

Fig. 1. Diagram showing a semi-closed system for measurement of oxygen consumption.

A chamber for blank tests was also placed in the same water bath to measure background oxygen consumption. In this respirometry system, the rate of oxygen consumption was determined in the light and in the dark 


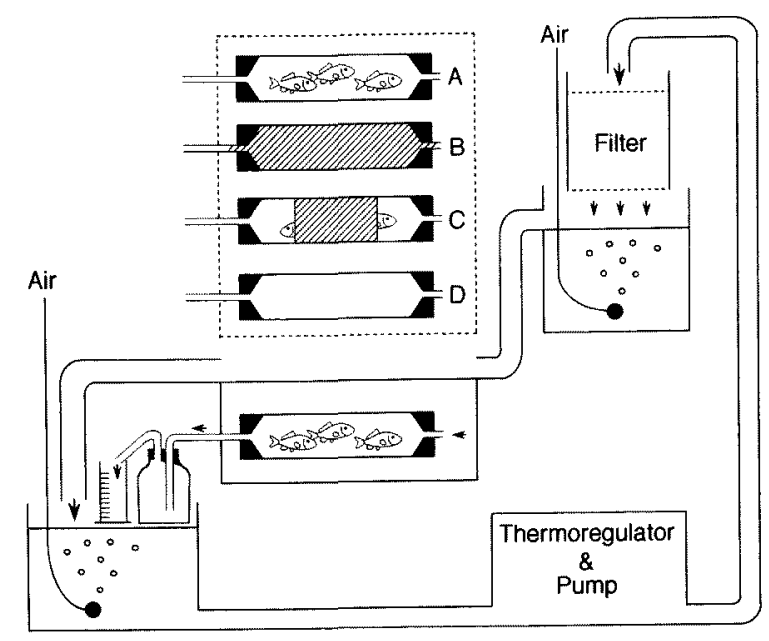

Fig. 2. Diagram showing the constant flow system for measurement of oxygen consumption.

A: not-covered, B: covered, C: half-covered, and D: chamber for blank tests.

and constant flow method (Fig. 2). Details of the two types of respirometry system are summarized in Table 1.

In the semi-closed method, a respiration chamber made of a bottle containing the fish was slowly irrigated with airsaturated water during intervals between measurements and closed during measurements. Oxygen consumption was calculated from the depletion of oxygen in water during the period of measurement.

In the constant flow method, a cylindrical respiration chamber was irrigated with air-saturated water at a constant flow rate. Oxygen consumption was calculated from the difference of oxygen concentration between the inflowing and outflowing water to and from the chamber and the flow rate of water through the chamber. A chamber for blank tests ${ }^{\text {s) }}$ was used to determine and eliminate the background oxygen consumption.

Oxygen consumption was repeatedly measured 1-3 times in the semi-closed method and 2-4 times in the constant flow method to get an average value for a single point in Figs. 3 and 4. Oxygen concentration in the water was determined by Winkler's titration method. Oxygen consumption was measured both in the light and in the dark. A dark condition was achieved by covering the respiration chamber by a film used for shielding photosensitive paper. Examples are shown in Fig. 2. Illumination was 80 lux at the surface of the water bath.

2. Metabolism in vitro $\left(M_{\text {in vitro }}\right)$ : The rate of oxygen consumption of minced tissue of whole body $\left(M_{\text {in vitro }}\right)$ was manometrically determined at $25^{\circ} \mathrm{C}$ after the following procedures. A sufficient number of fish to get a tissue preparation of about $0.2 \mathrm{~g}$ was immobilized in chilled Cortland saline. ${ }^{6}$ The immobilized fish were blotted with a filter paper to remove the saline, and then minced by chopping about 400 times with ophthalmic scissors in a chilled weighing bottle until the fish body became pasty. The minced sample was then suspended in physiological saline containing glucose, Na-pyruvate, Na-fumarate and Na-Lglutamate as substrates. ${ }^{1}$ The rate of oxygen consumption of the tissue preparation was measured by Warburg's manometer, shaking 120 times / min, using $20 \% \mathrm{KOH}$ solution as $\mathrm{CO}_{2}$ absorbent and ordinary air as the gas phase. The time from killing the fish to setting a minced sample in a Warburg flask was less than $20 \mathrm{~min}$ and the sample was kept chilled for this period. The manometer was read every $5 \mathrm{~min}$ for $60 \mathrm{~min}$ after thermal equilibration for 10 min, and oxygen consumption was determined by applying the least squares method to the results during the first $30 \mathrm{~min}$ which showed a linear relationship to time. Two to three determinations were done for the same minced sample, and the average value was used as the rate of oxygen consumption of the minced whole body.

\section{Results}

\section{Effect of Light Conditions}

In the semi-closed method, the mass-specific rate of oxygen consumption $\left(M / W\right.$ in $\left.\mu l \cdot \mathrm{g}^{-1} \cdot \mathrm{min}^{-1}\right)$ was higher in the light than in the dark $(p<0.001$ based on ANCOVA, analysis of covariance) (Fig. 3A). In the constant flow method, on the other hand, there was no substantial difference among the three different light conditions (Fig. 3B).

\section{Relationship between Oxygen Consumption and Body Mass}

The relationship between oxygen consumption of an individual fish ( $M$ in $\mu l \cdot \min ^{-1}$ ) and body mass ( $W$ in $\mathrm{g}$ ) was expressed by the allometric equation $M=\mathrm{a} W^{\mathrm{b}}$ (Fig. 4 and Table 2). There were three different allometric relationships depending on the method of respirometry (Fig. 4,

Table 1. Basic data of two different systems for respirometry used in this study

\begin{tabular}{|c|c|c|c|c|c|c|c|c|}
\hline \multirow{2}{*}{ Respirometry system } & \multirow{2}{*}{$\begin{array}{l}\text { Volume of } \\
\text { respiration } \\
\text { chamber }(\mathrm{ml})\end{array}$} & \multirow{2}{*}{$\begin{array}{c}\text { Size range of } \\
\text { fish examined } \\
\text { Wet mass in } \\
\text { grams } \\
\text { (Age in days) }\end{array}$} & \multirow{2}{*}{$\begin{array}{l}\text { No, of fish } \\
\text { placed in a } \\
\text { respiration } \\
\text { chamber }\end{array}$} & \multicolumn{2}{|c|}{$\begin{array}{l}\text { Period keeping fish in } \\
\text { respiration chamber }(h)\end{array}$} & \multirow{2}{*}{$\begin{array}{l}\text { Flow rate } \\
\text { of water } \\
\left(\mathrm{m} l \cdot \min ^{-1}\right)\end{array}$} & \multicolumn{2}{|c|}{$\begin{array}{c}\mathrm{O}_{2} \text { in water } \\
\text { in } \mathrm{m} / \cdot l^{-1}(\bar{X} \pm \mathrm{S} . \mathrm{D} .) \\
\text { (no. of measurements) }\end{array}$} \\
\hline & & & & $\begin{array}{c}\text { Before } \\
\text { measurement }\end{array}$ & $\begin{array}{l}\text { During } \\
\text { measurement }\end{array}$ & & $\begin{array}{l}\text { Initial or } \\
\text { at inflowing } \\
\text { water }\end{array}$ & $\begin{array}{c}\text { Final or } \\
\text { at outflowing } \\
\text { water }\end{array}$ \\
\hline Semi-closed system & $130-4100$ & $\begin{array}{c}0.0021-0.94 \\
(1-70)\end{array}$ & $18-3$ & $7-16.5$ & $10.4-6^{* 1}$ & $10-250$ & $5.48 \pm 0.14(83)$ & $4.46 \pm 0.49(99)$ \\
\hline Constant flow system & $31-240$ & $\begin{array}{r}0.039-3.5 \\
(49-79)\end{array}$ & $5-3$ & $4-7$ & $1-3^{* 2}$ & $2.5-44$ & $5.56 \pm 0.02(26)$ & $4.86 \pm 0.16(74)$ \\
\hline
\end{tabular}

*1 During this period, oxygen consumption was determined 1-3 times repeatedly

*2 During this period, oxygen consumption was determined 2-4 times at intervals of $1 \mathrm{~h}$. 


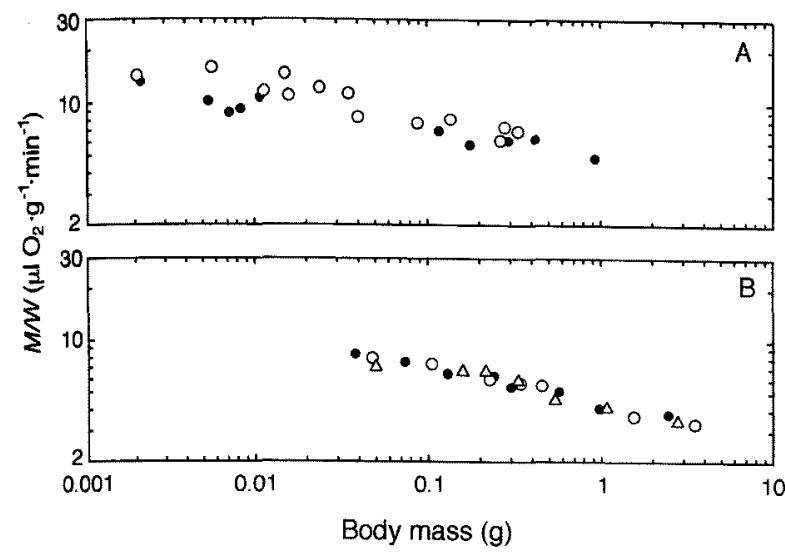

Fig. 3. Mass-specific rate of oxygen consumption $(M / W)$ in different light conditions in relation to body mass $(W)$, determined by semiclosed method (A) and constant flow method (B) ( $\bullet$ : respiration chamber was completely covered, $\triangle$ : half-covered, and $O$ : not covered).

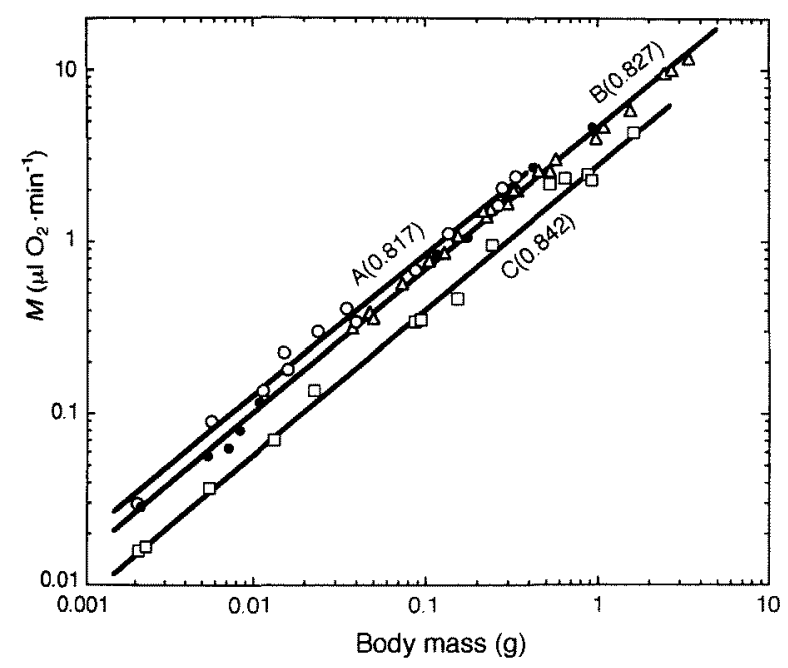

Fig. 4. Allometric relationships of oxygen consumption of an individual fish $(M)$ to body mass $(W)$ determined by three different methods of respirometry.

A: oxygen consumption in vivo of intact fish $M_{\text {in vivo }}$ by semiclosed method in the light (O), B: $M_{\text {in vivo }}$ by semi-closed method in the dark ( $\bullet$ ) and $M_{\text {in vivo }}$ by constant flow method in three different light conditions $(\triangle)$, and $C$ : oxygen consumption in vitro of minced fish $M_{\text {in vitro }}$ by manometry ( $\square$ ). Figures in parentheses indicate the slope of the lines or the " $\mathrm{b}$ " value in the equation $M=\mathrm{a} W$ ". Line A, $\mathrm{B}$ and $\mathrm{C}$ correspond to row $\mathrm{A}, \mathrm{B}$ and $\mathrm{C}$ in Table 2 . lines $\mathrm{A}, \mathrm{B}$ and $\mathrm{C}$; Table 2 , rows $\mathrm{A}, \mathrm{B}$ and $\mathrm{C}$. $M$ determined by the semi-closed method in the dark (Fig. 4, solid circles) was found to be identical to $M$ by the constant flow method (Fig. 4, triangles). Therefore these two sets of data were expressed by a single regression line (Fig. 4, line B; Table 2, row B). The mass exponent " $b$ " in the equation was significantly smaller than unity for any of the three lines $\mathrm{A}, \mathrm{B}$ and $\mathrm{C}(p<0.001)$.

ANCOVA showed that lines A, B and C are parallel (i.e. mass exponents " $\mathrm{b}$ " in $M=\mathrm{a} W^{\mathrm{b}}$ are identical to each other), but the levels of these lines were significantly different (i.e. mass coefficient " $a$ " in $M=\mathrm{a} W$ b is different) $(p<0.001)$. A common slope (mass exponent " $\mathrm{b}$ ") of lines $\mathrm{A}, \mathrm{B}$ and $\mathrm{C}$ was calculated to be 0.831 based on regression analysis, and the mass coefficient (" $\mathrm{a}$ " value) at $b=0.831$ was calculated to be 5.71 for line A, 4.56 for line B, and 2.70 for line $C$.

\section{Discussion}

\section{Metabolic Scaling}

Mass-specific metabolic rate $(M / W)$ decreased in vitro as well as in vivo with increasing body mass, independent of respirometry method. Mass exponent " $b$ " was smaller than unity and identical between in vivo and in vitro metabolic rates (Fig. 4, Table 2). This implies that the relationship between metabolism and size is fundamentally the same between in vivo and in vitro. These results correspond with those of our previous report for carp at $20^{\circ} \mathrm{C}^{7}$ and for porgy at $20^{\circ} \mathrm{C}^{3}{ }^{3}$ Von Bertalanffy and Pirozynski $i^{8)}$ proposed a metaphysical or non-experimental idea that the decrease in mass-specific metabolic rate of an intact animal is regulated by "factors lying in the organism as a whole". If "factors lying in the organism as a whole" exist, they should not exist in excised tissues. Therefore, the relationship between metabolism and body mass should be different between in vivo and in vitro. The results of our experiments that mass exponent " $b$ " was the same between in vivo and in vitro contradict the idea of Von Bertalanffy and Pirozynski. ${ }^{8}$

\section{Activity}

Mass coefficient " $\mathrm{a}$ " in $M=\mathrm{a} W^{\mathrm{b}}$ differed among the three methods, indicating different activity in the different methods of respirometry (Fig. 4, Table 2). The aerobic metabolism of fishes is categorized as standard (resting), resting routine, routine, swimming, and active metabolism. ${ }^{9}$ Standard metabolism is defined as the mini-

Table 2. Regression analyses of the allometric relationship $\left(M=\mathrm{a} W^{\mathrm{b}}\right)$ of oxygen consumption $\left(M\right.$ in $\left.\mu l \mathrm{O}_{2} \cdot \min ^{-1}\right)$ to body mass $(W$ in $\mathrm{g})$

\begin{tabular}{|c|c|c|c|c|c|c|}
\hline \multirow[b]{2}{*}{ Row } & \multirow{2}{*}{$\begin{array}{l}\text { Oxygen consumption determined by } \\
\text { different methods of respirometry }\end{array}$} & \multirow{2}{*}{$\begin{array}{l}\text { Range of } \\
\text { body mass } \\
\text { in grams } \\
\text { (Age in days) }\end{array}$} & \multirow[b]{2}{*}{$\mathbf{N}$} & \multicolumn{2}{|c|}{ Constants in the equation } & \multirow[b]{2}{*}{$\mathrm{r}$} \\
\hline & & & & $a$ & $(\bar{X} \pm$ S.E. $)$ & \\
\hline A & $\begin{array}{l}M_{\text {in vivo }} \text { determined by } \\
\text { semi-closed method in the light }\end{array}$ & $\begin{array}{c}0.0021-0.33 \\
(1-41)\end{array}$ & 13 & 5.46 & $0.817 \pm 0.024$ & 0.995 \\
\hline B & $\begin{array}{l}M_{\text {in vivo }} \text { determined by semi-closed method } \\
\text { in the dark and by constant flow method } \\
\text { in three different light conditions }\end{array}$ & $\begin{array}{r}0.0022-3.5 \\
(1-79)\end{array}$ & 32 & 4.53 & $0.827 \pm 0.008$ & 0.998 \\
\hline $\mathrm{C}$ & $M_{\text {in vitro }}$ determined by manometry & $\begin{array}{r}0.0021-1.7 \\
(3-76)\end{array}$ & 14 & 2.78 & $0.842 \pm 0.017$ & 0.998 \\
\hline
\end{tabular}


mum rate for intact fish, resting routine metabolism as the rate for quiescent fish, routine metabolism as the rate in fish in routine condition including spontaneous movement, swimming metabolism as the rate measured at some voluntary or forced level of swimming, and active metabolism as the maximum aerobic rate associated with swimming at the greatest sustainable velocity. $\left.{ }^{9}\right)$

In the semi-closed method, oxygen consumption was higher in the light than in the dark (Fig. 3A). In the constant flow method, on the other hand, the light condition did not have an effect on oxygen consumption (Fig. 3B). This difference is probably caused by different states of activity owing to different chamber size. The volume of the respiration chamber was roughly ten times larger in the semi-closed method than in the constant flow method (Table 1). In the semi-closed method, a relatively large chamber permits fish to swim spontaneously in the light, while in the constant flow method, a relatively small chamber constrains spontaneous swimming even in the light. We consider, therefore, that the activity of fish in the semiclosed method in the light represents the routine state, and the activity in the semi-closed system in the dark and that in the constant flow method represent the resting routine state.

The very low value of $M_{\text {in vitro }}$ obtained by manometry is considered to have been caused by lack of energy expenditure for locomotion, movement of opercula and fins, heart beat, peristalsis of the digestive tract and other physiological activities. ${ }^{3)}$ Therefore, the state of activity in $M_{\text {in vitro }}$ of the carp is considered to coincide with the basal part of the standard metabolism. However, $M_{\text {in vitro }}$ is probably not so far below the standard metabolism, because the standard metabolism of goldfish has been estimated by Winberg ${ }^{10)}$ to be about $60 \%$ of "average metabolism". "Average metabolism" by Winberg ${ }^{10)}$ is considered to represent the resting routine or routine metabolism. In the present study, $M_{\text {in vitro }}$ of the carp was $47 \%$ of the routine metabolism or $59 \%$ of the resting routine metabolism judg. ing from the " $\mathrm{a}$ " value in $M=\mathrm{a} W^{\mathrm{b}}$.

Acknowledgments We wish to thank Dr. K. Yamamoto, Shimonoseki University of Fisheries, for providing the carp eggs.

\section{References}

1) S. Oikawa and Y. Itazawa: Allometric relationship between tissue respiration and body mass in the carp. Comp. Biochem. Physiol. 77A, 415-418 (1984)

2) Y. Yamashita and K. M. Bailey: Electron transport system (ETS) activity as a possible index of respiration for larval walleye pollock Theragra chalcogramma. Nippon Suisan Gakkaishi, 56, 1059-1062 (1990).

3) S. Oikawa and Y. Itazawa: Relationship between metabolic rate in vitro and body mass in a marine teleost, porgy Pagrus major. Fish Physiol. Biochem., 10, 177-182 (1992).

4) E. Pfeiler and J. J. Govoni: Metabolic rates in early life history stages of elopomorph fishes. Biol. Bull. Mar. Biol. Lab., Woods Hole, 185, 277-283 (1993).

5) S. Oikawa, Y. Itazawa, and M. Gotoh: Ontogenetic change in the relationship between metabolic rate and body mass in a sea bream Pagrus major (Temminck \& Schlegel). J. Fish Biol., 38, 483-496 (1991).

6) K. Wolf: Physiological salines for fresh-water teleosts, Prog. Fish Cult., 25, 135-140 (1963).

7) Y. Itazawa and S. Oikawa: A quantitative interpretation of the metabolism-size relationship in animals. Experientia, 42, 152-153 (1986).

8) L. Von Bertalanffy and W. J. Pirozynski: Tissue respiration, growth, and basal metabolism. Biol. Bull. Mar. Biol. Lab., Woods Hole, 105, 240-256 (1953).

9) J. J. Cech, Jr.: Respirometry, in "Methods for Fish Biology" (ed. by C. B. Schreck and P. B. Moyle), American Fisheries Society, Bethesda, 1990, pp. 335-362.

10) G. G. Winberg: Rate of metabolism and food requirements of fishes. Fish. Res. Bd Can., Trans. Ser., 194, 1-202 (1956). 